\title{
Zarząd kablem światłowodowym stanowiącym przedmiot współwłasności przymusowej
}

\author{
Management of fiber optic cable constituting the subject \\ of compulsory co-ownership
}

mgr Adrian Malicki

E-mail: adrianmalicki@vp.pl

\begin{abstract}
Streszczenie
Ustawą z 7.05.2010 r. o wspieraniu rozwoju usług i sieci telekomunikacyjnych (u.w.r.u.s.t.) prawodawca wprowadził do polskiego porządku prawnego konstrukcję odrębnej własności części składowej rzeczy ruchomej. Stanowi to wyłom w dotychczasowym postrzeganiu konstrukcji prawnorzeczowych. Możliwości takiej nadal nie przewiduje jednak Kodeks cywilny. Ustanowienie odrębnej własności części składowej dotąd możliwe było jedynie w przypadku nieruchomości. Zgodnie z ustawą możliwe jest ustanowienie odrębnej własności włókna światłowodowego umieszczonego w kablu. Spełnienie ustawowych przesłanek nie powoduje automatycznego wyodrębnienia włókna z kabla światłowodowego. Osiągnięcie takiego skutku wymaga zajścia zdarzenia prawnego wskazanego w ustawie. Z chwilą ustanowienia odrębnej własności pierwszego włókna światłowodowego jednolita struktura prawna kabla światłowodowego ulega dekompozycji. Natomiast kabel stanowi odtąd przedmiot współwłasności przymusowej właścicieli włókien światłowodowych, co wymaga ich współdziałania. Sprawowanie zarządu częściami wspólnymi kabla światłowodowego oparte jest na odpowiednio stosowanych przepisach Kodeksu cywilnego o zarządzie rzeczą wspólną. Zasady te są modyfikowane regulacją ustawy o wspieraniu rozwoju sieci i usług telekomunikacyjnych.
\end{abstract}

Słowa kluczowe: zarząd rzeczą wspólną; kabel światłowodowy; współwłasność przymusowa kabla światłowodowego; zarząd kablem światłowodowym.

\section{Summary}

In Supporting the Development of Telecommunications Networks and Services Act of 7th May 2010 legislator introduced into the Polish legal structure of separate ownership constituent of movables. According to the Act of 7 May 2010 it is possible to establish separate ownership of the optical fiber placed in the cable. This is a breach in the existing perception of the design property rights. This possibility is still not in the Civil Code. Separation of ownership of the component previously was only possible in the case of real estate. The fulfillment of the conditions laid down in the act does not automatically extract the fiber optic cable. Achieving this effect requires the occurrence of an event specified in the act. At the time of the separate ownership of the first optical fiber, the uniform legal structure of the fiber optic cable is decomposed. The cable is hence the subject of compulsory co-ownership of fiber optic owners, which requires their cooperation. The management of the common parts of the fiber optic cable is based on properly applied provisions of the Civil Code regarding the management of the common property. These rules are modified by the Supporting the Development of Telecommunications Networks and Services Act of 7th May 2010.

Key words: management of the common property; fiber optic cable; compulsory co-ownership of the fiber optic cable; management of the fiber optic cable.

JEL: G20, K22

Str. 21-26 


\section{Bibliografia}

Cisek, A., Górska, K. (2013a). Komentarz do art. 199 k.c. W: E. Gniewek, P. Machnikowski (red.), Kodeks cywilny. Komentarz. Warszawa: C.H. Beck.

Cisek, A., Górska, K. (2013b). Komentarz do art. 200 k.c. W: E. Gniewek, P. Machnikowski (red.), Kodeks cywilny. Komentarz. Warszawa: C.H. Beck.

Cisek, A., Górska, K. (2013c). Komentarz do art. 201 k.c. W: E. Gniewek, P. Machnikowski (red.), Kodeks cywilny. Komentarz. Warszawa: C.H. Beck.

Cisek, A., Górska, K. (2013d). Komentarz do art. 202 k.c. W: E. Gniewek, P. Machnikowski, Kodeks cywilny. Komentarz. Warszawa: C.H. Beck.

Gniewek, E. (2013). Treść i wykonywanie prawa współwłasności. W: E. Gniewek (red.), System Prawa Prywatnego (t. 3). Prawo rzeczowe. Warszawa: C.H. Beck.

Gniewek, E. (2014). Prawo rzeczowe, Warszawa: C.H. Beck.

Grossman, T. (2013a). Komentarz do art. 38 u.w.r.u.s.t. W: T. Grossman et al., Ustawa o wspieraniu rozwoju ustug $i$ sieci telekomunikacyjnych. Komentarz. Warszawa: C.H. Beck.

Grossman, T. (2013b). Komentarz do art. 42 u.w.r.u.s.t. W: T. Grossman et al., Ustawa o wspieraniu rozwoju ustug $i$ sieci telekomunikacyjnych. Komentarz. Warszawa: C.H. Beck.

Ignatowicz, J. (1972a). Komentarz do art. 199 k.c. W: Z. Resich (red.), Kodeks cywilny. Komentarz (t. 1), Warszawa: Wydawnictwo Prawnicze.

Ignatowicz, J. (1972b). Komentarz do art. 200 k.c. W: Z. Resich (red.), Kodeks cywilny. Komentarz (t. 1), Warszawa: Wydawnictwo Prawnicze.

Ignatowicz, J. (1972c). Komentarz do art. 203 k.c. W: Z. Resich (red.), Kodeks cywilny. Komentarz (t. 1), Warszawa: Wydawnictwo Prawnicze.

Ignatowicz, J., Stefaniuk, K. (2012). Prawo rzeczowe, Warszawa: LexisNexis

Karnicka-Kawczyńska, A., Kawczyński J. (2000). Zarząd rzeczą wspólna (na gruncie przepisów kodeksu cywilnego), Prawo Spótek (6), 30-41.

Księżak, P. (2017a). Komentarz do art. 202 k.c. W: K. Osajda (red.), Kodeks cywilny. Komentarz (t. 2). Warszawa: C.H. Beck. Księżak, P. (2017b). Komentarz do art. 209 k.c. W: K. Osajda (red.), Kodeks cywilny. Komentarz (t. 2). Warszawa: C.H. Beck. Malicki, A. (2017). Umowa jako sposób ustanowienia odrębnej własności włókna światłowodowego. Rejent (3), $28-50$.

Midwinter, J. E. (1983). Świattowody telekomunikacyjne. Warszawa: Wydawnictwa Naukowo-Techniczne.

Nowakowski, Z. K. (1977). Współwłasnosć. W: J. Ignatowicz (red.), System Prawa Cywilnego (t. 2), Wrocław: Ossolineum.

Skowrońska-Bocian, E., Warciński, M. (2015). Komentarz do art. 199 k.c. W: K. Pietrzykowski (red.), Kodeks cywilny. Komentarz (t. 1) Art. 1-44910. Warszawa: C.H. Beck.

Szadkowski, K. (2016). Komentarz do art. 209 k.c. W: M. Gutowski (red.), Kodeks cywilny (t. 1) Komentarz do art. 1-44911. Warszawa: C.H. Beck.

Szydło, W. (2010). Ustanawianie odrębnej własności części składowych rzeczy ruchomych — niedopuszczalny wyłom systemowy czy gospodarcza konieczność? W: J. Gołaczyński, P. Machnikowski (red.), Współczesne problemy prawa prywatnego. Księga pamiątkowa ku czci Profesora Edwarda Gniewka (603-615). Warszawa: C.H. Beck.

Uliasz, M. (2002). Czynności przekraczające zakres zwykłego zarządu (cz. 1), Monitor Prawniczy (18), 825-831.

Uliasz, M. (2004). Czynności zachowawcze (art. 209 k.c.) w świetle orzecznictwa Sądu Najwyższego, Przegląd Sądowy (4), 75-95.

Uliasz, M. (2003). Glosa do uchwały SN z 19.04.2002 r., Orzecznictwo Sąów Polskich (7-8), 94.

Ziembiński, Z. (2012). Logika praktyczna, Warszawa: Wydawnictwo Naukowe PWN.

\section{Akty prawne}

Ustawa z 17.11.1964 r. - Kodeks postępowania cywilnego (Dz. U. z 2018 r. poz. 1360 ze zm.)

Ustawa z 23.04.1964 r. — Kodeks cywilny (Dz. U. z 2018 r. poz. 1025 ze zm.).

Ustawa z 7.05.2010 r. o wspieraniu rozwoju usług i sieci telekomunikacyjnych (Dz. U. z 2017 r. poz. 2062 ze zm.).

\section{Orzecznictwo}

Postanowienie SN z 21.11.1980 r., III CRN 166/80, LEX nr 2597.

Uchwała SN (7) z 10.04.1991 r., III CZP 76/90, LEX nr 3659.

Uchwała SN (7) z 25.03.1994 r., III CZP 182/93, LEX nr 4025.

Uchwała SN z 10.10.2014 r., III CZP 71/14, LEX nr 1521329.

Wyrok SA w Poznaniu z 7.02.2006 r., I ACa 829/05, LEX nr 203647. 